\title{
Foreign Direct Investment, Exports, and Long-Run Economic Growth in Asia: Panel Cointegration and Causality Analysis
}

\author{
Seng Sothan ${ }^{1}$ \\ ${ }^{1}$ College of Business Management, Life University, Sihanoukville, Cambodia \\ Correspondence: Seng Sothan, College of Business Management, Life University, Sihanoukville, Cambodia. \\ E-mail: sothans@yahoo.com
}

Received: November 4, 2015

Accepted: December 2, 2015 Online Published: December 25, 2015

doi:10.5539/ijef.v8n1p26

URL: http://dx.doi.org/10.5539/ijef.v8n1p26

\begin{abstract}
This paper examines the co-movement and causal impact of foreign direct investment (FDI) and exports on economic growth in 21 Asian countries over the period 1980 to 2013, using the panel cointegration and Granger causality analysis. Findings strongly confirm that there is a long-run steady-state relationship between FDI, exports, and GDP for the selected countries. Based on the panel Granger causality analysis, there is long-run bidirectional causality between FDI and GDP and between exports and GDP. This can be concluded that FDI and exports do have causal impact on long-run growth in the countries being investigated.
\end{abstract}

Keywords: economic growth, exports, foreign direct investment, panel cointegration, panel Granger causality

\section{Introduction}

Many policy makers and economists believe that foreign direct investment (FDI) has positive impact on economic growth and development in a recipient economy. However, for many decades, there have been voluminous debates on the costs and benefits of inward FDI. Some researchers believe that FDI provides direct financing for capital investment. Aside from this, FDI is also confirmed to be a source of both knowledge and technology spillovers, particularly through its linkages with local firms. The spillovers will later spread to the rest of the economy.

To gain FDI benefits, both the developed and the developing countries have formulated the policies that offer incentives to attract foreign firms to their countries. However, FDI also has its own costs in a host economy. For example, FDI might put more pressure on competition for many local firms in national markets, particularly small and medium enterprises, if FDI does not concentrate on the export sector. In addition, FDI can also deteriorate the balance of payment when the repatriations of profits occur. Some even argue that FDI can have crowding-out effects on domestic investment. In this perspective, the effects of foreign direct investment on growth are ambiguous. The interaction between FDI and economic growth has been a subject of debate among economists and researchers for many decades. The debate is mostly related to whether FDI has positive impact on economic growth as predicted by theory or not. Another important debate is concerned with how FDI contributes to economic growth. Theoretically, FDI is believed to positively contribute to economic growth and generate positive productivity externalities. However, empirical findings seem inconclusive. Some studies support the view that FDI has positive impact on growth (e.g. Nair-Reichert \& Weinhold, 2001; Yao \& Wei, 2007; Vu, Gangnes, \& Noy, 2008), but some still confirm FDI to have growth effects in a host economy only with a strong financial system (Alfaro et al., 2004) and high human capital (Borensztein et al., 1998). However, some studies do not support the FDI-led growth hypothesis (Kholdy, 1995; Duasa, 2007; Mutafoglu, 2012; Mohamed et al., 2013). Aside from FDI, exports are also a significant determinant of growth. The relationship between trade openness, particularly exports, and economic growth has been a main issue of debate in development literature for decades. Some studies support the export-led growth hypothesis (e.g. Tyler, 1981; Chow, 1987; Bahmani-Oskooee \& Alse, 1993) but others do not support the view (Jung \& Marshall, 1985; Ahmad \& Kwan, 1991). In this perspective, empirical findings on the growth impact of exports are still inconclusive.

For the past few decades, many countries in Asia have received voluminous inward FDI and moved from the import-substitution to export-promotion policies, but the growth impact of both FDI and exports is found to be differential across countries. The differential conditions are mostly attributed to low human capital, low financial 
development, geography, trade policies, and severe economic and social issues. In other words, most findings on the growth impact of FDI and exports are based on the conventional estimation techniques, such as the OLS, GMM, and country-specific time series analysis; therefore, the present paper is an attempt to reexamine the co-movement and long-run causality between FDI, exports, and economic growth in a panel of 21 Asian countries based on the panel cointegration and Granger causality analysis.

The rest of the article is organized as follows. Section 2 reviews literature on the impact of FDI and exports on economic growth. Section 3 discusses the modeling framework for estimation. The fourth section illustrates the estimation results, and the final section concludes the study and provides some policy implications.

\section{Literature Review}

\subsection{FDI-Growth Nexus}

In the neoclassical growth model proposed by Harrod (1939), Domar (1946), and Solow (1956), FDI promotes economic growth by increasing the quantity of total investment. In the endogenous growth model introduced based on the initial works of Romer (1986) and Lucas (1988), FDI enhances economic growth by generating technological and knowledge spillovers from the developed world to the developing economies. Based on the two types of growth models, FDI is an important contributor of economic growth in a host economy. Empirically, Bende-Nabende and Ford (1998) investigate the impact of FDI on growth in Taiwan. Findings support the FDI-led growth hypothesis. Later, Yao and Wei (2007) also find FDI to be a powerful driver of economic growth for China. The finding is also corroborated by others (e.g. Zhang, 1999; Vu et al., 2008). In addition, other researchers confirm the same finding for a number of Asian countries, including Vietnam ( Vu, Gangnes, \& Noy, 2008), Thailand (Mandal, 2012), Indonesia (Suyanto et al., 2012), Pakistan (Rahman \& Shahbaz, 2013), and so on.

Beside country-specific studies, Nair-Reichert and Weinhold (2001) examine the relationship between FDI and growth in developing countries and find that there is a causal link between FDI and growth. Campos and Kinoshita (2002) also confirm FDI to have positive impact on growth as predicted by theory. Later, Li and Lui (2005) investigate the growth impact of FDI for a penal of 84 countries over the period 1970 to1999, using both single equation and simultaneous equation techniques. They do not find the endogenous relationship between FDI and economic growth for the whole period, but only from the mid-1980s onward. This indicates that before the mid-1980s, FDI does not positively contribute to growth. It may be due to some severe economic and social conditions that occur in many developing countries that cannot turn inward FDI into growth-enhancing FDI. In other words, they stress that FDI not only directly promotes economic growth by itself, but also does so via its interaction with human capital. Hansen and Rand (2006) investigate the causal relationship between FDI and economic growth in a sample of 31 developing countries, using the Granger causal analysis. They find bi-directional causality between FDI and economic growth. Most recently, with the use of recent data, Oladipo (2013) examines the impact of FDI on growth in a panel of 16 countries in the Latin American and Caribbean regions. The researcher finds FDI to have causal impact on economic growth in 13 out of the 16 countries, indicating that FDI really plays a very significant role in the selected countries. Although the above-mentioned researchers support the growth impact of FDI, this impact is likely to be differential and conditional on various factors, including the level of human capital, financial market development, macroeconomic conditions, institutional quality, economic freedom, corruption, and trade openness across recipient economies (Borenszteina et al., 1998; Noorbakhsh et al., 2001; Alfaro et al., 2004; Hansen \& Rand, 2006). For instance, Borenszteina et al. (1998) examine the growth impact of FDI in 69 developing countries over the last two decades. They find FDI to have a positive effect on economic growth only when sufficient absorptive capability of the advanced technologies is available in a recipient country. In their analytical frame-work, the level of human capital determines the ability to adopt foreign technology. The above findings are also consistent with other empirical evidence (Olofsdotter, 1998; Bengoa \& Sanchez-Robles, 2003).

Although the above researchers mainly focus on the role of human capital in generating growth and in producing positive externalities of FDI, other researchers also confirm that the growth impact of FDI not only depends on the level of human capital or the available technology in a host country, but it also depends on the financial market development in a host economy. Recent studies by Alfaro et al. (2004) seek to bridge this gap between the theoretical and empirical literature. The model used is based on a mechanism that emphasizes the role of local financial markets in turning FDI into growth-enhancing FDI through the creation of backward linkages. Their findings show that FDI alone plays an ambiguous role in generating growth and that an increase in FDI stimulates higher economic growth in financially developed countries than financially poorly-developed ones.

Contrary to the above findings, Kholdy (1995) carries out Granger causality test, using data from 10 East Asian 
economies to examine the growth impact of FDI. Findings do not confirm the causation between FDI and productivity. The explanation offered is that FDI may generate only limited efficiency spillovers and may be a less important vehicle for technology transfer than was previously thought. Later, Herzer et al. (2008) investigate the impact of FDI on economic growth in 28 developing countries, using co-integration techniques on a country-by-country basis. They find that there exists neither a long-run nor a short-run effect of FDI on economic growth in a vast majority of countries. Their findings provide no clear association between FDI and the level of per capita income in the developing countries in their sample of study. Most recently, Herzer (2012) provides empirical evidence on the growth impact of FDI for a panel of 44 developing countries based on the panel cointegration analysis. FDI is found to have negative impact on economic growth in a vast majority of countries. In addition, similar inferences are also drawn by Tekin (2012) who examines the causal impact of FDI on economic growth in 18 least-developed countries, using data for the period 1970 to 2009. They find FDI to Granger cause GDP in only two countries and GDP to Granger cause FDI in 4 countries. Based on the empirical findings of this study, FDI does not help promote economic growth in the least-developed countries being investigated. The above findings indicate the impact of FDI on economic growth to be debatable. From this perspective, it can be concluded that the role of FDI in growth enhancing seems to be country-based, depending on the economic, institutional, human capital, and technological conditions in a recipient economy.

\subsection{Export-Growth Nexus}

Turning to exports, there has been voluminous literature on the export-growth nexus. The topic has caught international attention among researchers and policy makers around the globe. Since the 1960s, many economists (e.g. Hultman, 1967; Krueger, 1978) provide arguments that export promotion is an important development strategy. There are some reasons given in support of export promotion. Exports encourage production specialization which later leads to increase in productivity gains. In addition, resources will be efficiently allocated through exports, particularly via shifting factors of production to the export sector. Export growth also produces greater economies of scale (Balassa, 1978). Based on the economic theory, export growth positively contributes to economic growth through the effect of its multiplier. Although theoretical studies support the export-led growth hypothesis, empirical findings are still inconclusive. For example, Emery (1967), Tyler (1981), Kavoussi (1984), Chow (1987), and Moschos (1989) examine the relationship between exports and economic growth based on the correlational and regression analysis. Results show that there is a positive relationship between exports and growth; therefore, they suggest that exports are an important driver of economic growth across countries.

However, many studies show mixed findings on the impact of exports on economic growth across countries. For example, Ahmad and Harnhirun (1995) examine the causal impact of exports on growth in ASEAN countries, including Indonesia, Malaysia, the Philippines, Singapore, and Thailand, using data for the period 1966 to1990. Based on the cointegration and Granger causality test results, exports are confirmed to have causal impact on growth only in Singapore. This indicates that exports do not seem to have causal impact on growth in other ASEAN countries under investigation. Later, Pereira and Xu (2000) analyzed the effects of export growth on GDP, domestic employment, and investment in 39 economies. They find that 30 out of the 39 countries show a positive long-run effect of export growth on GDP. Based on the findings, they conclude that the positive effects of export growth on GDP are consistent with the export-led growth hypothesis. However, in the study, six countries show negative effects of export growth on GDP. The two researchers suggest that this case may be due to political and economic instability. In addition, Tekin (2012) examines the causal impact of exports on economic growth in 18 least-developed countries, using data for the period 1970 to 2009. They find unidirectional causality running from exports to GDP in only three countries and from GDP to exports in three countries. Based on the empirical findings of this study, exports do not help promote economic growth in the least-developed countries being investigated. Most recently, Tang et al. (2015) re-examined the export-led growth hypothesis for Asia's four Little Dragons, using cointegration and the modified Wald causality test. Findings show that exports and GDP are cointegrated for all the four economies, implying that there is a long-run relationship between the variables. Based on the modified Wald causality test results, bidirectional causality between exports and GDP is confirmed only for Hong Kong and Singapore, but causality running from exports to GDP is not confirmed in South Korea and Taiwan. Other researchers, including Jung and Marshall (1985), Colombatto (1990), and Ahmad and Kwan (1991) do not corroborate with the findings that exports lead growth. Among them, Colombatto (1990) investigate the export-led growth hypothesis for a sample of 70 less developed countries by employing ordinary least square estimation procedure. Results reject the export-led growth hypothesis. In this perspective, findings on the impact of exports on GDP are still inconclusive. 


\section{Data and Methodology}

\subsection{Data Descriptions}

Based on the objective of the study, economic growth (GDP) is a function of FDI and exports. The empirical model is accordingly specified as follows:

$$
\log (G D P)_{i t}=\alpha_{i}+\delta_{i} t+\beta_{1 i} \log (F D I)_{i t}+\beta_{2 i} \log (X)_{i t}+\varepsilon_{i t}
$$

where $\log (G D P)_{i t}$ denotes the natural logarithm of real GDP over time periods $t=1,2, \ldots, T$ and countries $i=1,2, \ldots, N . \log (F D I)_{i t}$ and $\log (X)_{i t}$ represent the natural logarithm of foreign direct investment stock and exports as a percentage of GDP, respectively, over the same time periods and countries. All the data are gathered from the United Nations Conference on Trade and Development (UNCTAD) database published in 2015. The impact of FDI and exports on economic growth is hypothesized to be positive as confirmed in theory. $\varepsilon_{i t}$ is the residual of Eq.(1), which later is used to examine the causality between FDI, exports, and GDP based on the panel Granger causality analysis if the panel cointegration tests discover the co-movement among the variables in the system. All the data employed cover the period 1980 to 2013, which is a critical period that reflects the era of globalization and the economic integration of the countries being investigated. In other words, this period is also assumed to be long enough to generate a long-run relationship among the variables under consideration. Why does the present paper choose this period and the two estimation methods for analysis?

It is because, before this period, numerous developing countries performed centrally-planned economies and some were not fully open to the rest of the world. Most importantly, majority of these countries had suffered from severe social and economic issues. In this perspective, FDI and exports may not have played an important role in stimulating economic growth. For example, $\mathrm{Li}$ and $\mathrm{Liu}$ (2005) examine the impact of FDI on growth for a panel of 84 countries, using data for the period 1970 to 1999. They find FDI to have statistically significant and positive impact on growth only for the period 1985 to 1999, but not for the whole period. Recently, Herzer (2012) also performs an empirical analysis on the growth impact of FDI, using data for the period 1970 to 2005. The researcher finds FDI to have negative impact on economic growth in a vast majority of countries because the author did not break the period. Similar inferences are also drawn by Tekin (2012) who examines the causal impact of FDI on economic growth in 18 least-developed countries, using data for the period 1970 to 2009. They find FDI to Granger cause GDP in only two countries. Turning to exports, many researchers, including Jung and Marshall (1985) and Colombatto (1990) do not find positive interactions between exports and economic growth in their selected countries. Based on causality analysis, many findings confirm non-causality running from exports to GDP (e.g. Dodaro, 1991; Ahmad \& Kwan, 1991; Bahmani-Oskooee et al., 1991). Besides, many previous studies that confirm exports to have positive relationship with growth are mostly based on correlational analysis (Emery, 1967; Tyler, 1981; Kavoussi, 1984; Moschos, 1989), but this estimation method cannot confirm causality among the variables investigated. This can be inferred that the negative or insignificant impact of exports on growth may also be attributed to the period of study or the methods employed for estimation.

Therefore, the present paper decides to choose the recent period 1980 to 2013 for investigation. In addition, the empirical analysis is based on the panel cointegration and Granger causality techniques, which are recently and widely employed for panel analysis. The findings of the present study may provide more empirical content regarding the co-movement and causal interactions among FDI, exports, and GDP in addition to what was found decades ago.

\subsection{The Panel Unit Root Tests}

Non-stationary data normally provide spurious empirical results while using in the OLS estimation technique. Before choosing an appropriate econometric model, it is imperative to examine the unit root of all the variables and to determine the degree to which they are integrated. However, panel data contribute to the increase in the number of observations, which in turn leads to increase in the power of the tests. Empirically, many studies rely on panel unit root tests in order to increase the statistical power of the findings. Among these tests, the Fisher test with reference to the ADF test (Dickey \& Fuller, 1979) proposed by Maddala and Wu (1999, hereafter ADF Fisher) is confirmed to be more powerful than other unit root tests developed by Levin and Lin (1992, 1993, hereafter LLC) and Im et al. (1997, 2003, hereafter IPS). Therefore, this paper conducts the unit root test developed by Maddala and $\mathrm{Wu}$ (1999). The ADF regression for each cross-section is defined as follows:

$$
\Delta X_{i t}=\alpha_{i}+\rho_{i} t+\beta X_{i t-1}+\sum_{j=1}^{k} \gamma_{i} \Delta X_{i t-j}+\varepsilon_{i t}
$$

where $i(i=1, \ldots, N)$ denotes the number of panel and $\mathrm{t}(t=1, \ldots T)$ denotes time periods. $\Delta$ is the first-difference operator; $k$ is the lag length. $\alpha_{i}$ is the unit-specific effect. Let $\pi_{i}$ then denote the asymptotic $\mathrm{p}$-value of a unit root test for cross section $i$. Under the null hypothesis of unit root for all cross-sections, 
Maddala and $\mathrm{Wu}$ (1999) propose a non-parametric test statistic with reference to the ADF test as $-2 \sum_{i=1}^{N} \ln \pi_{i} \sim X^{2}$ with 2 Nd.f, where $N$ is the number of separate samples. The null hypothesis is that each series in the panel has a unit root, $\pi_{i}=0$, for all $\mathrm{i}$, and the alternative hypothesis is that not all of the individual series have a unit root, $\pi_{i}<0$, for the other $i$. Finally, Maddala and Wu (1999) conclude that the Fisher test is simple and straightforward to use and superior to the LLC and IPS tests. Therefore, in this paper, the Fisher test is particularly conducted.

\subsection{Panel Cointegration Analysis and FMOLS Approach}

The paper carries out the panel cointegration tests proposed by Pedroni (1999) to examine the long-run equilibrium relationship among the variables under consideration. To test for the null hypothesis of no-cointegration against the alternative hypothesis of the cointegration in the panel, Pedroni (1999) proposed seven tests which are divided into two types. The first type is based on the within-dimension approach, which includes four statistics. They are panel v-statistic, panel rho-statistic, panel PP-statistic, and panel ADF-statistic. Pedroni (2004) indicates that the within-dimension approach is based on the estimators that effectively pool the autoregressive coefficients across different members for the unit root tests on the estimated residuals. In this approach, the cointegrating vectors may be heterogeneous across members of the panel in general. The second test by Pedroni (1999) is based on the between-dimension approach, which includes three statistics. They are group rho-statistic, group PP-statistic, and group ADF-statistic. The between-dimension approach is based on the estimators that simply average the individually estimated coefficients for each member in the panel. In other words, Pedroni (2004) also state that the distributions of these seven test statistics are all asymptotically standard normal. Each of these tests is able to accommodate individual specific short-run dynamics, individual specific fixed effects, and deterministic trends as well as individual specific slope coefficients. The rejection of no-cointegration for the panel indicates long-run relationships among the variables in the system. In addition, the Kao residual cointegration test (Kao, 1999) is also performed as an alternative to check the cointegration among the series under consideration. Once the cointegration relationship is established, the next step is to estimate the long-run parameters. The test statistics proposed by Pedroni (1999) are defined as follows:

Panel v-statistic

$$
Z_{v}=\left(\sum_{i=1}^{N} \sum_{i=1}^{T} \hat{L}_{11 i}^{-2} \hat{e}_{i t-1}^{2}\right)^{-1}
$$

Panel $\rho$-statistic

$$
Z_{\rho}=\left(\sum_{i=1}^{N} \sum_{i=1}^{T} \hat{L}_{11 i}^{-2} \hat{e}_{i t-1}^{2}\right)^{-1} \sum_{i=1}^{N} \sum_{t=1}^{T} \hat{L}_{11 i}^{-2}\left(\hat{e}_{i t-1} \Delta \hat{e}_{i t}-\hat{\gamma}_{i}\right)
$$

Panel PP-statistic

$$
Z_{t}=\left(\hat{\sigma}^{2} \sum_{i=1}^{N} \sum_{i=1}^{T} \hat{L}_{11 i}^{-2} \hat{e}_{i t-1}^{2}\right)^{-1 / 2} \sum_{i=1}^{N} \sum_{t=1}^{T} \hat{L}_{11 i}^{-2}\left(\hat{e}_{i t-1} \Delta \hat{e}_{i t}-\hat{\gamma}_{i}\right)
$$

Panel ADF-statistic

$$
Z_{t}^{*}=\left(\hat{s}^{* 2} \sum_{i=1}^{N} \sum_{i=1}^{T} \hat{L}_{11 i}^{-2} \hat{e}_{i t-1}^{* 2}\right)^{-1 / 2} \sum_{i=1}^{N} \sum_{t=1}^{T} \hat{L}_{11 i}^{-2} \hat{e}_{i t-1}^{*} \Delta \hat{e}_{i t}^{*}
$$

Group $\rho$-statistic

$$
\tilde{Z}_{\rho}=\sum_{i=1}^{N}\left(\sum_{t=1}^{T} \hat{e}_{i t-1}^{2}\right)^{-1} \sum_{t=1}^{T}\left(\hat{e}_{i t-1} \Delta \hat{e}_{i t}-\hat{\gamma}_{i}\right)
$$

Group PP-statistic

$$
\tilde{Z}_{t}=\sum_{i=1}^{N}\left(\hat{\sigma}^{2} \sum_{t=1}^{T} \hat{e}_{i t-1}^{2}\right)^{-1 / 2} \sum_{t=1}^{T}\left(\hat{e}_{i t-1} \Delta \hat{e}_{i t}-\hat{\gamma}_{i}\right)
$$

Group ADF-statistic

$$
\tilde{Z}_{t}^{*}=\sum_{i=1}^{N}\left(\sum_{t=1}^{T} \hat{e}_{i t-1}^{* 2} \hat{s}_{i}^{2}\right)^{-1 / 2} \sum_{t=1}^{T}\left(\hat{e}_{i t-1}^{*} \Delta \hat{e}_{i t}^{*}\right)
$$

where $\hat{\gamma}_{i}=\frac{1}{2}\left(\hat{\sigma}_{i}^{2}-\hat{s}_{i}^{2}\right)$ for which $\hat{\sigma}_{i}^{2}$ and $\hat{s}_{i}^{2}$ are the long-run and individual contemporaneous variances, respectively, of the residual $\hat{u}_{i t}$ of the autoregression $\hat{u}_{i, t}=\hat{e}_{i, t}-\hat{\gamma}_{i} \hat{e}_{i, t-1} \cdot \hat{e}_{i t}$ is the estimated residual received from Eq.(1) and the $\hat{L}_{11 i}^{2}$ is the estimated long-run covariance matrix for $\Delta \hat{e}_{i t}$ (Note 1). The long-run parameters are estimated through the use of group-mean FMOLS (Note 2) developed by Pedroni (2000) for heterogeneous panel. The group-mean FMOLS estimator can simply be constructed as $\hat{\beta}_{G F M}^{*}=N^{l} \sum_{i=1}^{N} \hat{\beta}_{F M, i}^{*}$, where $\hat{\beta}_{F M, i}^{*}$ is obtained from the conventional FMOLS estimation of Eq.(1), applied to each member of the panel with the associated t-statistic of $t_{\widehat{\beta}_{G F M}^{*}}=\frac{1}{\sqrt{N}} \sum_{i=1}^{N} t_{\widehat{\beta}_{F M, i}^{*}}$. This FMOLS technique allows for considerable 
heterogeneity across individual members of the panel. However, the panel cointegration analysis does not indicate causality between the variables in the study; therefore, in this perspective, the panel Granger causality test is also performed to examine the causal interactions among the variables being investigated.

\subsection{Panel Granger Causality Test}

Since the cointegration analysis does not confirm the direction of causality, it is common to examine causality among the series if cointegration is established between them. In this case, the panel Granger causality analysis is used to determine the long-run and the short-run relationships among the variables in the system (Engle \& Granger, 1987); therefore, this paper also performs the test to examine causal interactions among the variables being investigated, namely FDI, exports, and GDP. The panel Granger causality test with a dynamic error correction is specified as follows:

$$
\begin{gathered}
\Delta \log (G D P)_{i t}=\alpha_{1 i}+\sum_{j=1}^{n} \alpha_{11 i j} \Delta \log (G D P)_{i t-j}+\sum_{j=1}^{n} \alpha_{12 i j} \Delta \log (F D I)_{i t-j}+\sum_{j=1}^{n} \alpha_{13 i j} \Delta \log (X)_{i t-j}+\theta_{1 i} \varepsilon_{i t-1}+u_{1 i t} \\
\Delta \log (F D I)_{i t}=\alpha_{2 i}+\sum_{j=1}^{n} \alpha_{21 i j} \Delta \log (F D I)_{i t-j}+\sum_{j=1}^{n} \alpha_{22 i j} \Delta \log (G D P)_{i t-j}+\sum_{j=1}^{n} \alpha_{23 i j} \Delta \log (X)_{i t-j}+\theta_{2 i} \varepsilon_{i t-1}+u_{2 i t} \\
\Delta \log (X)_{i t}=\alpha_{3 i}+\sum_{j=1}^{n} \alpha_{31 i j} \Delta \log (X)_{i t-j}+\sum_{j=1}^{n} \alpha_{32 i j} \Delta \log (G D P)_{i t-j}+\sum_{j=1}^{n} \alpha_{33 i j} \Delta \log (F D I)_{i t-j}+\theta_{3 i} \varepsilon_{i t-1}+u_{3 i t}
\end{gathered}
$$

where $\Delta$ denotes first-difference operator and $\mathrm{n}$ is the optimal lag length(s). In the present paper, the maximum number of lags is two based on the Schwarz information criteria (SIC). $\varepsilon_{i t}$ is the residuals obtained from the panel FMOLS estimation of Eq.(1). The panel Granger causality test is used to examine both the short-run and long-run causality. The short-run causality is determined based on the Wald test, particularly the F-statistic. The long-run causality is examined by statistical significance of the t-statistic on the error correction parameter, $\theta$. The coefficients of the error correction terms, namely, $\theta_{1}, \theta_{2}$ and $\theta_{3}$, indicate causality in the long run.

\section{Findings and Discussion}

Determining the order of integration of the variables is a crucial step in an empirical analysis since using the conventional OLS approach with non-stationary variables may result in spurious regressions. In other words, many recent studies rely on panel unit root tests in order to increase the statistical power of their empirical findings. Although the panel unit root tests developed by Levin and Lin (1992, 1993, henceforth LLC) and Im et al. (1997, 2003, henceforth IPS) are widely utilized in panel cointegration studies, there are some criticisms on the weaknesses of the two tests. Therefore, the unit root test developed by Maddala and Wu (1999) is mainly applied in this paper. Maddala and $\mathrm{Wu}$ (1999) conclude that the Fisher test is simple and straightforward to use. The test is also confirmed to be superior to the LLC and IPS tests. Findings on the unit root properties of the variables at their level and first difference are reported in Table 1. It is clear from the Fisher test results that the null hypothesis of the unit root cannot be rejected at levels for all variables. The results indicate a uniform conclusion that all the variables are nonstationary. However, the test statistics for the first difference strongly reject the null hypothesis, implying that all the variables are stationary at first difference, I(1).

Table 1. Results for the panel unit root tests

\begin{tabular}{lcc}
\hline Variables & \multicolumn{2}{c}{ ADF } \\
\cline { 2 - 3 } & Constant & Constant and trend \\
\hline LogGDP & 39.649 & 30.263 \\
LogFDI & 57.001 & 46.738 \\
$\log X$ & 45.837 & 36.478 \\
$\Delta(\operatorname{LogGDP})$ & $220.644^{*}$ & $218.269^{*}$ \\
$\Delta(\operatorname{LogFDI})$ & $336.538^{*}$ & $303.106^{*}$ \\
$\Delta(\log X)$ & $309.026^{*}$ & $245.748^{*}$ \\
\hline
\end{tabular}

Note. $*$ denotes the significance level of $1 \%$.

The results can proceed to the test of cointegration among the series being investigated based on the panel cointegration test developed by Pedroni (1999). The main objective of the paper is to examine the co-movement and long-run causality between FDI, exports, and economic growth for a panel of 21 Asian countries. Results of the panel cointegration tests (Pedroni, 1999) are presented in Table 2. Majority of the test statistics significantly reject the null of no cointegration with constant and trend, except for the panel rho-statistic, the group rho-statistic, and the group PP-statistic. In other words, results of the Kao residual cointegration test (Note 3) 
(Kao, 1999) also reject the null hypothesis of no cointegration at the 1 percent level. This indicates strong evidence of cointegration among the variables in the study. Thus, it can be inferred that FDI, exports, and GDP move together in the long-run. That is, there is a long-run steady-state relationship or co-movement among FDI, exports, and GDP for the countries under investigation. The long-run elasticities of growth with respect to FDI and exports for each of the 21 countries and for the panel based on the group-mean FMOLS estimation technique are reported in Table 3.

Table 2. Results for panel cointegration tests

\begin{tabular}{lll}
\hline Test & Constant & Constant and Trend \\
\hline Panel v-Statistic & -0.965 & $41.064^{* *}$ \\
Panel rho-Statistic & 1.994 & 0.369 \\
Panel PP-Statistic & 2.201 & $-2.106^{*}$ \\
Panel ADF-Statistic & 2.000 & $-3.384^{* *}$ \\
Group rho-Statistic & 2.723 & 1.867 \\
Group PP-Statistic (non-parametric) & 2.202 & -1.093 \\
Group ADF-Statistic (non-parametric) & 2.208 & $-2.852^{* *}$ \\
\hline
\end{tabular}

Note. $*$ and $* *$ denote the significance levels of $5 \%$ and $1 \%$, respectively.

Beginning with the country-specific results, it is found that FDI has significantly positive impact on GDP in 19 out of the 21 countries. However, the coefficients of FDI for Hong Kong and New Papua Guinea are negative, although not statistically significant at the conventional level. The magnitude of the impact of FDI on growth ranges from 2.6842 in Sri Lanka to -0.2374 in New Papua Guinea. This can be inferred that the growth impact of FDI seems to be differential across countries.

Table 3. Results of the FMOLS estimations

\begin{tabular}{lll}
\hline Countries & $\log (\mathrm{FDI})$ & $\log (\mathrm{X})$ \\
\hline Afghanistan & $0.122^{* *}$ & $-0.516^{* *}$ \\
Bangladesh & $0.744^{* *}$ & $0.905^{* *}$ \\
Bhutan & $0.641^{* *}$ & $1.613^{* *}$ \\
Brunei & $0.053^{* *}$ & 0.289 \\
Cambodia & $0.482^{* *}$ & $0.423^{* *}$ \\
China & $0.554^{* *}$ & $1.819^{* *}$ \\
Hong Kong & -0.122 & $1.489^{* *}$ \\
India & $0.4185^{* *}$ & $1.137^{* *}$ \\
Republic of Korea & $0.657^{* *}$ & $1.606^{* *}$ \\
Laos & $0.248^{* *}$ & $0.620^{*}$ \\
Malaysia & $1.583^{* *}$ & $1.681^{* *}$ \\
Myanmar & $0.171^{*}$ & $0.613^{* *}$ \\
Nepal & $0.296^{* *}$ & 0.214 \\
Pakistan & $0.627^{* *}$ & $2.254^{* *}$ \\
New Papua Guinea & -0.237 & $1.081^{* *}$ \\
the Philippines & $0.667^{* *}$ & $0.634^{* *}$ \\
Singapore & $0.979^{* *}$ & $4.114^{* *}$ \\
Sri Lanka & $2.684^{* *}$ & -0.303 \\
Taiwan & $1.219^{* *}$ & $1.674^{*}$ \\
Thailand & $0.577^{* *}$ & $1.179^{* *}$ \\
Vietnam & $0.334^{* *}$ & $1.438^{* *}$ \\
Panel FMOLS & $0.607^{* *}$ & $1.144^{* *}$ \\
\hline
\end{tabular}

Note. * and $* *$ denote the significance levels of $5 \%$ and $1 \%$, respectively.

Turning to the effects of exports on GDP, exports are found to have significantly positive impact on growth in 17 out of the 21 countries. However, the coefficients of exports for two countries, Nepal and Brunei, are insignificantly positive and two other countries, namely Afghanistan and Sri Lanka, show negative impact of 
exports on growth. The cases may be attributed to political and economic instability. The impact magnitude of exports ranges from 4.114 in Singapore to -0.5163 in Afghanistan. Based on the findings in Table 3, the group-mean FMOLS parameters for the panel show that FDI and exports have positive and statistically significant impact on GDP, but the growth elasticity for FDI is small relative to the growth elasticity for exports. A $1 \%$ increase in FDI increases GDP by only $0.6074 \%$, while a $1 \%$ increase in exports increases GDP by $1.1442 \%$. Although exports play a more important role in stimulating growth, findings suggest that the two variables are major drivers of long-run economic growth in the selected countries. The paper is also an attempt to determine long-run causality between the variables based on the panel Granger causality analysis.

The source of causation can be identified by testing the significance of the coefficients of the dependent variables in Eqs. (3), (4), and (5). Generally, the short-run effect is assumed to be transitory. Before performing the panel Granger causality test, selecting the optimal lag length is so important because the number of lags may influence the results of the test, particularly the F-statistic. In this paper, the number of lags chosen is two based on the Schwarz information criteria (SIC). The panel Granger causality results are reported in Table 4. Findings show that the F-statistics for FDI and exports obtained from the Wald test are not significant at the conventional level ( $p>0.1$ ), indicating that there is no short-run panel causality running from both FDI and exports to GDP. Exports and GDP are also not found to have short-run causal impact on FDI. However, short-run causality is found to run from GDP to exports. The main objective of the present paper is to determine the long-run causality between FDI, exports, and economic growth. Based on the findings in Table 4, the long-run coefficients (ECT) of FDI, export, and GDP equations are negative and statistically significant at the $1 \%$ level. The findings seem to be supported by theory, which confirm that the two variables are the main drivers of economic growth. Based on the panel Granger causality results, there is long-run bidirectional causality between FDI and GDP. This implies that FDI is an important vehicle of growth in the selected countries and vice versa. When economic growth is achieved, it designates better macroeconomic performance, which in turn leads to increase in confidence among foreign investors to invest in these Asian countries.

Table 4. Panel granger causality results

\begin{tabular}{lcccc}
\hline Dependent & \multicolumn{3}{c}{ Short-run Causality } & \multirow{2}{*}{ Long-run Causality } \\
\cline { 2 - 4 } variables & $\Delta(\log G D P)$ & $\Delta(\operatorname{LogFDI})$ & $\Delta(\log X)$ & $-0.028^{*}$ \\
\hline$\Delta(\log G D P)$ & - & $\mathrm{F}=2.392$ & $\mathrm{~F}=0.151$ & $-0.073^{*}$ \\
$\Delta(\operatorname{LogFDI})$ & $\mathrm{F}=1.645$ & - & $\mathrm{F}=2.877$ & $-0.099^{*}$ \\
\hline$(\operatorname{LogX})$ & $\mathrm{F}=5.699^{*}$ & $\mathrm{~F}=0.394$ & - & \\
\hline
\end{tabular}

Note. The $\mathrm{F}$ values denote F-statistics and $*$ denotes the significance level of $1 \%$.

The findings of the present paper not only support the FDI-led growth hypothesis, but also the growth-led FDI hypothesis. Similar deductions are corroborated by Nair-Reichert and Weinhold (2001), and Hansen and Rand (2006) who confirm FDI to have positive impact on growth in host economies. On the contrary, findings of the present study are not validated by a number of studies. For example, Azman-Saini et al. (2010) investigate the impact of FDI and economic freedom on economic growth for a panel of 85 countries, using data for the period 1976 to 2004. They did not break the period of the study. Findings confirm that FDI does not have direct impact on economic growth for the countries under their consideration. However, they confirm FDI to have positive impact on growth only when interacted with economic freedom. Recently, Herzer (2012) also performs an empirical analysis on the growth impact of FDI, using data for the period 1970 to 2005 . The researcher found FDI to have negative impact on economic growth in a huge majority of countries because the author did not break the period. Similar deduction is also confirmed by Li and Liu (2005) who examine the impact of FDI on growth for the period 1970 to 1999 . They find FDI to have statistically significant and positive impact on growth, but this growth impact exists only for the period 1985 to 1999, not for the whole period. Based on the above findings, the present study suggests that the growth impact of FDI may exist only after the 1970s.

Turning to exports, findings suggest that there is bidirectional causality between exports and GDP in the long run, implying that there is proof to support the export-led growth hypothesis and growth-led export hypothesis. Any country that exports more will generate more growth and vice versa. The country that produces more will export more to other countries. The same findings are also confirmed by Chandra Parida and Sahoo (2007). On the contrary, some studies do not support the findings of the present paper that exports lead to economic growth. For example, Bahmani-Oskooee et al. (1991) employed Granger causality test to examine causality between exports and GDP for the period 1951 to 1986 . The authors find exports to have no causal impact on growth in a vast 
majority of countries. Later, Dodaro (1993) examines the causal impact of exports on GDP, using data for the period 1967 to 1986 for a sample of 87 developing countries based on Granger causality analysis. The researcher finds exports to have no causal impact on GDP in a vast majority of countries (73 countries). The same deductions are also confirmed by Tekin (2012). The researcher finds unidirectional causality running from exports to GDP in only three countries and from GDP to exports in three countries out of the 18 countries under investigation.

\section{Conclusion and Policy Implications}

The paper is an attempt to reexamine the co-movement and causal impact of FDI and exports on GDP for 21 Asian countries from 1980 to 2013 based on the panel cointegration and Granger causality tests. Our empirical findings suggest that there is a long-run steady-state relationship between FDI, exports, and GDP for the countries being investigated. The period used in this paper is considered to be long enough for the co-movement and causality in the long run. Both theoretically and empirically, there is voluminous literature on the impact of FDI and exports on economic growth across countries. Although most theoretical studies confirm a positive relationship between FDI, exports, and economic growth, some empirical studies do not support this view. Findings of the present paper confirm FDI and exports to have causal impact on long-run economic growth across the Asian countries under investigation. This can be concluded that FDI and exports are really important contributors of long-run growth. Although the findings are not consistent with some previous studies, the inconsistency that occurs may be due to the impact of the period selected for investigation. The estimation methods used in previous studies for analysis might produce differences in empirical results as well. In other words, the quality of data might also produce biased results.

Based on findings of this paper, policy makers should focus on the policies that are export-based and attractive to inward FDI. Most importantly, the government in the selected countries should produce good macroeconomic environments, sustain social and political stability, improve physical infrastructure, develop export-based development strategy, remove all types of barriers to attract more FDI, and promote the financial sector development. Finally, for future research, attention should also be paid on the estimation methods and the period selected for analysis, particularly for developing countries or it will produce biased results regarding the growth impact of FDI and exports.

\section{Acknowledgements}

The author would like to thank Life University for the grant package, the editor, and the anonymous referees of this journal for their thoughtful comments and suggestions which improved this paper. Any remaining errors are my responsibility.

\section{References}

Ahmad, J., \& Harnhirun, S. (1995). Unit roots and cointegration in estimating causality between exports and economic growth: Empirical evidence from the ASEAN countries. Economics Letters, 49, 329-334. http://dx.doi.org/10.1016/0165-1765(95)00678-9

Ahmad, J., \& Kwan, A. C. (1991). Causality between exports and economic growth: Empirical evidence from Africa. Economics Letters, 37(3), 243-248. http://dx.doi.org/10.1016/0165-1765(91)90218-A

Alfaro, L., Chanda. A, Kalemli-Ozcan, S., \& Sayek, S. (2004). FDI and economic Growth: The role of local financial markets. Journal of International Economics, 64(1), 89-112. http://dx.doi.org/10.1016/S00221996(03)00081-3

Bahmani-Oskooee, M., \& Alse, J. (1993). Export growth and economic growth: An application of cointegration and error-correction modeling. The Journal of Developing Areas, 27(4), 535-542.

Bahmani-Oskooee, M., Mohtadi, H., \& Shabsigh, G. (1991). Exports, growth, and causality in LDCs: Areexamination. Journal of Development Economics, 36, 405-415. http://dx.doi.org/10.1016/03043878(91)90044-V

Balassa, B. (1978). Exports and economic growth: Further evidence. Journal of Development Economics, 5(2), 181-189. http://dx.doi.org/10.1016/0304-3878(78)90006-8

Bende-Nabende, A. V. R. O. M., \& Ford, J. L. (1998). FDI, policy adjustment and endogenous growth: Multiplier effects from a small dynamic model for Taiwan, 1959-1995. World Development, 26(7), 1315-1330. http://dx.doi.org/10.1016/S0305-750X(98)00043-6

Bengoa, M., \& Sanchez-Robles, B. (2003). Foreign direct investment, economic freedom and growth: New evidence from Latin America. European Journal of Political Economy, 19(3), 529-545. 
http://dx.doi.org/10.1016/S0176-2680(03)00011-9

Borensztein, E., De Gregorio, J., \& Lee, J. W. (1998). How does foreign direct investment affect economic $\begin{array}{llll}\text { growth? Journal of International } & \text { Economics, }\end{array}$ http://dx.doi.org/10.1016/S00221996(97)00033-0

Campos, N. F., \& Kinoshita, Y. (2002). Foreign direct investment as technology transferred: Some panel evidence from the transition economies. The Manchester School, 70(3), 398-419. http://dx.doi.org/10.1111/1467-9957.00309

Chandra Parida, P., \& Sahoo, P. (2007). Export-led growth in South Asia: A panel cointegration analysis. International Economic Journal, 21(2), 155-175. http://dx.doi.org/10.1080/10168730701345414

Chow, P. C. (1987). Causality between export growth and industrial development: Empirical evidence from the NICs. Journal of Development Economics, 26(1), 55-63.

Colombatto, E. (1990). An analysis of exports and growth in LDCs. Kyklos, 43(4), 579-597. http://dx.doi.org/10.1111/j.1467-6435.1990.tb02238

Dickey, D. A., \& Fuller, W. A. (1979). Distribution of the estimators for autoregressive time series with a unit root. Journal of the American Statistical Association 74, 427-431. http://dx.doi.org/10.1080/01621459.1979.10482531

Dodaro, S. (1993). Exports and growth: A reconsideration of causality. Journal of Developing Areas, 27 , 227-244.

Domar, E. D. (1946). Capital expansion, rate of growth, and employment. Econometrica, 14, 137-147.

Duasa, J. (2007). Malaysian foreign direct investment and growth: Does stability matter. Journal of Economic Cooperation, 28(2), 83-98.

Emery, R. F. (1967). The relation of exports and economic growth. Kyklos, 20(4), 470-486. http://dx.doi.org/10.1111/j.1467-6435.1967.tb00859

Engle, R. F., \& Granger, C. W. J. (1987). Cointegration and error correction: Representation, estimation and testing. Econometrica, 55(2), 251-276.

Hansen, H., \& Rand, J. (2006). On the causal links between FDI and growth in developing countries. The World Economy, 29(1), 21-41. http://dx.doi.org/10.1111/j.1467-9701.2006.00756

Harrod, R. (1939). An essay in dynamic theory. Economic Journal, 49(193), 14-33.

Herzer, D. (2012). How does foreign direct investment really affect developing countries' growth? Review of International Economics, 20(2), 396-414. http://dx.doi.org/10.1111/j.1467-9396.2012.01029

Herzer, D., Klasen, S., \& Nowak-Lehmann, D. F. (2008). In search of FDI-led growth in developing countries: The way forward. Economic Modeling, 25(5), 793-810. http://dx.doi.org/10.1016/j.econmod

Hultman, C. W. (1967). Exports and economic development: A survey. Land Economics, 43(2), 148-157.

Im, K. S., Pesaran, M. H., \& Shin, Y. (1997). Testing for Unit Roots in Heterogeneous Panels. Mime Department of Applied Economics, University of Cambridge.

Im, K. S., Pesaran, M. H., \& Shin, Y. (2003). Testing for unit roots in heterogeneous panels. Journal of Econometrics, 115(1), 53-74. http://dx.doi.org/10.1016/S0304-4076(03)00092-7

Jung, W. S., \& Marshall, P. J. (1985). Exports, growth and causality in developing countries. Journal of Development Economics, 18(1), 1-12. http://dx.doi.org/10.1016/0304-3878(85)90002-1

Kao, C. (1999). Spurious regression and residual-based tests for cointegration in panel data. Journal ofEconometrics, 90(1), 1-44. http://dx.doi.org/10.1016/S0304-4076(98)00023-2

Kavoussi, R. M. (1984). Export expansion and economic growth: Further empirical evidence. Journal of Development Economics, 14(1), 241-250. http://dx.doi.org/10.1016/0304-3878(84)90052-X

Kholdy, S. (1995). Causality between foreign investment and spillover efficiency. Applied Economics, 27(8), 745-749. http://dx.doi.org/10.1080/00036849500000064

Levin, A., \& Lin, C. F. (1992). Unit Root Test in Panel Data: Asymptotic and Finite Sample Properties. Discussion Paper, University of California at San Diego, 92-93.

Levin, A., \& Lin, C. F. (1993). Unit Root Test in Panel Data: New Results. Discussion Paper, University of 
California at San Diego, pp. 93-56.

Li, X., \& Liu, X. (2005). Foreign direct investment and economic growth: An increasingly endogenous relationship. World Development, 33(3), 393-407. http://dx.doi.org/10.1016/j.worlddev

Lucas, R. E. (1988). On the mechanics of economic development. Journal of Monetary Economics, 22(1), 3-42. http://dx.doi.org/10.1016/0304-3932(88)90168-7

Maddala, G. S., \& Wu, S. (1999). A comparative study of unit root tests with panel data and a new simple test. Oxford Bulletin of Economics and Statistics, 61, 631-652. http://dx.doi.org/10.1111/14680084.0610s1631

Mandal, K. (2012). Foreign direct investment and economic growth: An analysis for selected Asian countries. Journal of Business, 4(1), 15-24.

Mohamed, M. R., Singh, K. S. J., \& Liew, C. Y. (2013). Impact of foreign direct investment and domestic investment on economic growth of Malaysia. Malaysian Journal of Economic Studies, 50(1), 21-35.

Moschos, D. (1989). Export expansion, growth and the level of economic development: An empirical analysis. Journal of Development Economics, 30(1), 93-102. http://dx.doi.org/10.1016/03043878(89)90052-7

Mutafoglu, T. H. (2012). Foreign direct investment, pollution, and economic growth evidence from Turkey. Journal of Developing Societies, 28(3), 281-297. http://dx.doi.org/10.1177/0169796X12453780

Nair-Reichert, U., \& Weinhold, D. (2001). Causality tests for cross-country panels: A New look at FDI and economic growth in developing countries. Oxford Bulletin of Economics and Statistics, 63(2), 153-171. http://dx.doi.org/10.1111/1468-0084.00214

Noorbakhsh, F., Paloni, A., \& Youssef, A. (2001). Human capital and FDI inflows to developing countries: New $\begin{array}{llll}\text { empirical } & \text { evidence. }\end{array}$ http://dx.doi.org/10.1016/S0305-750X(01)00054-7

Oladipo, O. S. (2013). Does foreign direct investment cause long run economic growth? Evidence from the Latin American and the Caribbean countries. International Economics and Economic Policy, 10(4), 569-582. http://dx.doi.org/10.1007/s10368-012-0225-4

Olofsdotter, K. (1998). Foreign direct investment, country capabilities and economic growth. Review of World Economics, 134(3), 534-547. http://dx.doi.org/10.1007/BF02707929

Pedroni, P. (1999). Critical values for cointegration tests in heterogeneous panels with multiple regressors. Oxford Bulletin of Economics and Statistics, 61, 653-670. http://dx.doi.org/10.1111/1468-0084.0610s1653

Pedroni, P. (2000). Fully modified OLS for heterogeneous cointegrated panels. Advances in Econometrics, 15, 93-130.

Pedroni, P. (2004). Panel cointegration: Asymptotic and finite sample properties of pooled time series tests with an application to the PPP hypothesis. Econometric Theory, 20, 597-625. http://dx.doi.org/10.1017/S0266466604203073

Pereira, A. M., \& Xu, Z. (2000). Export growth and domestic performance. Review of International Economics, 8(1), 60-73. http://dx.doi.org/10.1111/1467-9396.00205

Rahman, M. M., \& Shahbaz, M. (2013). Do imports and foreign capital inflows lead economic growth? Cointegration and causality analysis in Pakistan. South Asia Economic Journal, 14(1), 59-81. http://dx.doi.org/10.1177/1391561413477941

Romer, P. M. (1986). Increasing return and long run growth. Journal of Political Economy, 94(5), 1002-1037.

Solow, R. M. (1956). A contribution to the theory of economic growth. Quarterly Journal of Economics, 70(1), 65-94.

Suyanto, B. H., \& Salim, R. A. (2012). Foreign direct investment spillovers and productivity growth in Indonesian garment and electronics manufacturing. The Journal of Development Studies, 48(10), 1397-1411. http://dx.doi.org/10.1080/00220388.2011.646992

Tang, C. F., Lai, Y. W., \& Ozturk, I. (2015). How stable is the export-led growth hypothesis? Evidence from Asia's four little dragons. Economic Modeling, 44, 229-235. http://dx.doi.org/10.1016/j.econmod

Tekin, R. B. (2012). Economic growth, exports, and foreign direct investment in least-developed countries: A panel Granger causality analysis. Economic Modeling, 29, 868-878. http://dx.doi.org/10.1016/j.econmod

Tyler, W. G. (1981). Growth and export expansion in developing countries: Some empirical evidence. Journal of 
Development Economics, 9(1), 121-130. http://dx.doi.org/10.1016/0304-3878(81)90007-9

$\mathrm{Vu}, \mathrm{T}$. B., Gangnes, B., \& Noy, I. (2008). Is foreign direct investment good for growth? Evidence from sectoral analysis of China and Vietnam. Journal of the Asia Pacific Economy, 13(4), 542-562. http://dx.doi.org/10.1080/13547860802364976

Yao, S., \& Wei, K. (2007). Economic growth in the presence of FDI: The perspective of newly industrializing economies. Journal of Comparative Economics, 35(1), 211-234. http://dx.doi.org/10.1016/j.jce

Zhang, K. H. (1999). Foreign direct investment and economic growth: Evidence from ten East Asian economies. International Economics, 52(4), 517-535.

\section{Notes}

Note 1. See Pedroni (1999) for the detailed descriptions of the seven test-statistics.

Note 2. See Pedroni (2000) for the detailed descriptions of the group-mean FMOLS technique.

Note 3. The Kao residual cointegration test is also conducted. However, findings of the test are not shown in the paper. The t-statistic of the test $(\mathrm{Kao}, 1990)$ is -2.366 and statistically significant at the $1 \%$ level $(\mathrm{p}<0.01)$.

\section{Copyrights}

Copyright for this article is retained by the author(s), with first publication rights granted to the journal.

This is an open-access article distributed under the terms and conditions of the Creative Commons Attribution license (http://creativecommons.org/licenses/by/3.0/). 